\title{
Economic optimization of selective dry cow treatment
}

\author{
C. G. M. Scherpenzeel, ${ }^{* 1}$ H. Hogeveen, $¥ \ddagger$ L. Maas, $\ddagger$ and T. J. G. M. Lam$†$ \\ *GD Animal Health, PO Box 9, 7400 AA Deventer, the Netherlands \\ †Utrecht University, Department of Farm Animal Health, PO Box 80151, 3508 TD Utrecht, the Netherlands \\ ¥Wageningen University and Research, Business Economics Group, PO Box 8130, 6700 EW Wageningen, the Netherlands
}

\begin{abstract}
The objective of this study was to develop a mathematical model to identify a scenario with the lowest costs for mastitis associated with the dry period while restricting the percentage of cows to be dried off with dry cow antimicrobials. Costs of clinical and subclinical mastitis as well as antimicrobial use were quantified. Based on data from a large field trial, a linear programming model was built with the goal to minimize the costs associated with antimicrobial use at drying off. To enable calculations on minimizing costs of dry cow treatment on herd-level by drying-off decisions in an "average" herd, we created an example herd. Cows were projected on 3 different types of herds, based on bulk tank somatic cell count, and were categorized in groups based on parity and somatic cell count from the last test recording before drying-off. Economically optimal use of antimicrobials was determined while restricting the maximum percentage of cows dried off with antimicrobials from 100 to $0 \%$. This restriction reveals the relationship between the maximum percentage of cows dried off with antibiotics and the economic consequences. A sensitivity analysis was performed to evaluate the effect of variation in the most important input variables, with the effect of dry cow antimicrobials resulting in a lower or higher percentage of clinical and subclinical mastitis depending on being dried off with or without dry cow antimicrobials, respectively, and the milk price. From an economic perspective, blanket dry cow treatment seems not to be the optimal approach of dry cow therapy, although differences between approaches were small. With lower bulk tank somatic cell counts, more dry cow antimicrobials can be omitted without economic consequences. The economic impact of reducing the percentage of clinical mastitis was found to be much larger than reducing the bulk tank somatic cell count. The optimal percentage of cows to be dried off with antimicrobials depends on the udder
\end{abstract}

Received April 25, 2017.

Accepted September 28, 2017.

${ }^{1}$ Corresponding author: c.scherpenzeel@gdanimalhealth.com health situation, expressed as the bulk tank somatic cell count and the incidence of clinical mastitis. For all evaluated types of herds, selective dry cow treatment was economically more beneficial than blanket dry cow treatment. Economic profits of selective dry cow treatment are greater if bulk tank somatic cell count and clinical mastitis incidence are lower. Economics is not an argument against reduction of dry cow antimicrobials by applying selective dry cow treatment.

Key words: linear programming, mastitis, antimicrobial reduction, dry cow treatment, economics

\section{INTRODUCTION}

Control of mastitis is of major importance for the dairy sector. Apart from other consequences, mastitis leads to high monetary costs because of treatment, discarded milk, and major production losses (Hogeveen et al., 2011). In the dairy industry, antimicrobials are mainly used for treatment of clinical mastitis (CM) and dry cow treatment (DCT). For many years, approximately $60 \%$ of the antimicrobial use (AMU) in dairy cows in the Netherlands was related to mastitis, of which roughly two-thirds related to DCT (Kuipers et al., 2016).

One of the points recommended since the 1970s in the 5 Points Mastitis Control Plan (Neave et al., 1969) was blanket dry cow treatment (BDCT) to control the risk of new IMI during the dry period (Dodd et al., 1969). The main goal of DCT was to reduce the prevalence of IMI, both by eliminating IMI present at drying off and preventing new IMI from occurring during the dry period (Bradley and Green, 2001). In many countries, more than $90 \%$ of all dairy cows were treated with antibiotics during the dry period [e.g., $94 \%$ in the Netherlands (Lam et al., 2013) and 99\% in the United Kingdom (Berry and Hillerton, 2002)].

Due to public health concerns and risk for antimicrobial resistance (AMR), prudent and restricted use of antimicrobials is promoted and preventive use of antimicrobials for all food animals has been prohibited since 2012 in the Netherlands (Santman-Berends et al., 2016). Selective dry cow treatment (SDCT), not using 
DCT in cows that had a low SCC at the last milk recording before drying off, significantly increased the incidence rate of CM as well as SCC postpartum in a study in the Netherlands (Scherpenzeel et al., 2014).

A meta-analysis done by Halasa et al. (2009a) showed that BDCT seemed to protect better against new IMI than SDCT, which seemed to protect better than no DCT at all. It was also shown that the decrease in AMU due to SDCT was substantial and by no means compensated by an increase in AMU due to an increased incidence rate of CM (Scherpenzeel et al., 2016).

The effect of SDCT compared with BDCT on udder health, AMU, and economics is influenced by the criteria used to select cows for DCT (Cameron et al., 2014; Scherpenzeel et al., 2016). The chosen criteria have an effect on quantifiable parameters, such as CM incidence, AMU, and economics, but also nonquantifiable parameters, such as welfare and practical feasibility. These effects can be contradictory; SDCT as compared with BDCT leads to more CM cases and a higher SCC, whereas it decreases AMU substantially (Scherpenzeel et al., 2014). Udder health, welfare, production losses, $\mathrm{AMU}$, and economic consequences are all parameters that are influenced by decisions on $\mathrm{DCT}$, but that potentially move in different directions. Additionally, although the relationship between AMU and development of AMR in mastitis pathogens is complex and unclear (Oliver et al., 2011), there is a potential effect of AMU on the development of AMR (Chantziaras et al., 2014). In decision making of farmers, this can, however, be considered as an externality because these consequences are experienced by the environment or society while they are not necessarily directly experienced by the farmer. A common way to quantify different parameters, with the exception of animal welfare and public health, is in economic units. As such, economic consequences along with animal welfare, legislation, and public health concerns, may be helpful in making decisions on animal health strategies.

A few studies describe the economic consequences of DCT. Most economic analyses have concluded that BDCT is financially beneficial, because of increased milk yield, lower SCC, or reduced CM cases, when compared with SDCT or no DCT (McNab and Meek, 1991; Berry et al., 1997; Yalcin and Stott, 2000). Most of these calculations were, however, based on uncertain assumptions and the results had much variation. In a study done by Huijps and Hogeveen (2007), SDCT was economically most attractive. In that study, however, differences between BDCT and SDCT were small and with regard to selection of the appropriate animals, the assumptions for DCT were rough. None of the above studies described the level of reduction of AMU while practicing SDCT.
The economic impact of SDCT likely varies for different types of herds and for different levels of DCT use. Studies describing and evaluating economic consequences of SDCT on the herd level can be used by dairy farmers and their advisors to help them to optimize decisions on DCT, thereby minimizing costs. Thus, the economic consequences of decisions on DCT need further attention. Therefore the objective of this study was to develop a mathematical model to minimize economic costs while restricting the percentage of cows to be dried off with DCT, accounting for effects of CM, subclinical mastitis (SCM), and AMU.

\section{MATERIALS AND METHODS}

A randomized controlled field trial was carried out between June 2011 and March 2012 in the Netherlands in which the effect of DCT on CM, bacteriological status, SCC, and AMU was evaluated (Scherpenzeel et al., 2014). Based on these data, data from literature for high-SCC cows dried off with antimicrobials (Barkema et al., 1998) and smoothed data based on regression analysis for high-SCC cows dried off without antimicrobials (data not shown) a linear programming (LP) model was built with the goal to minimize the costs associated with AMU at drying off. In this model different approaches of selecting cows for DCT were compared based on the SCC at the last milk recording before drying off (Scherpenzeel et al., 2016). A timeframe of 1 yr was used to take seasonal differences into account and to represent the financial planning horizon of dairy farmers. The general purpose of an LP approach is to maximize or minimize a goal variable (e.g., maximize profit or minimize costs) by finding the optimal combination of different parameters with respect to a set of fixed constraints. Microsoft Excel (Microsoft Corp., Redmond, WA) was used to develop and run the LP model, using the Simplex Algorithm for optimization.

\section{Definition of the Herd}

To enable calculations on minimizing costs of DCT on herd-level by drying-off decisions in an "average" herd, we created an example herd. Cows that were dried off at the end of their first lactation were referred to as first dry period (FDP) cows at drying off, during the dry period and the first 100 DIM of the subsequent lactation. Cows that were dried off for the second or later time were referred to as multiple dry period (MDP) cows at drying off, during their dry period and the first 100 DIM of the subsequent lactation.

Nine cow groups $(i=1-9)$ were considered, consisting of 4 classes of FDP cows $(0-50,000$ cells $/ \mathrm{mL}$; 51,000-100,000 cells/mL; 101,000-150,000 cells/mL; 
Table 1. Distribution of cows at drying-off in groups (1-9) in a 75-cow example herd, based on their SCC $\left(\times 10^{3}\right.$ cells $\left./ \mathrm{mL}\right)$ and parity at the last milk recording before drying off for a low-bulk tank SCC (BTSCC) herd $\left(\mathrm{BT}_{\mathrm{L}}\right)$, an average-BTSCC herd $\left(\mathrm{BT}_{\mathrm{A}}\right)$, and a high-BTSCC herd $\left(\mathrm{BT}_{\mathrm{H}}\right)$, and cow-level incidence of clinical mastitis $\left(\mathrm{I}_{\mathrm{CM}}\right)$ and subclinical mastitis $\left(\mathrm{I}_{\mathrm{SCM}}\right)$ when dried off with $(j=1)$ or without $(j=2)$ dry cow antimicrobials

\begin{tabular}{|c|c|c|c|c|c|c|c|c|c|}
\hline \multirow[b]{2}{*}{ Group } & \multirow[b]{2}{*}{$\mathrm{SCC}$} & \multirow[b]{2}{*}{ Parity $^{1}$} & \multicolumn{3}{|c|}{$\begin{array}{l}\text { Number of cows included } \\
\text { in the model }\end{array}$} & \multicolumn{2}{|c|}{$\mathrm{I}_{\mathrm{CM}}(\%)$} & \multicolumn{2}{|c|}{$\mathrm{I}_{\mathrm{SCM}}(\%)$} \\
\hline & & & $\mathrm{BT}_{\mathrm{L}}$ & $\mathrm{BT}_{\mathrm{A}}$ & $\mathrm{BT}_{\mathrm{H}}$ & $j=1$ & $j=2$ & $j=1$ & $j=2$ \\
\hline 1 & $0-50$ & FDP & 14 & 10 & 4 & 9.9 & 11.8 & 4.8 & 7.2 \\
\hline 2 & $51-100$ & FDP & 6 & 7 & 4 & 9.1 & 10.8 & 10.6 & 19.0 \\
\hline 3 & $101-150$ & FDP & 2 & 3 & 3 & 13.5 & 18.2 & 8.2 & 17.7 \\
\hline 4 & $>150$ & FDP & 3 & 5 & 14 & 14.4 & 20.0 & 11.3 & 25.0 \\
\hline 5 & $0-50$ & MDP & 28 & 7 & 8 & 12.8 & 20.1 & 7.3 & 17.3 \\
\hline 6 & $51-100$ & MDP & 13 & 10 & 9 & 15.2 & 26.8 & 13.6 & 18.8 \\
\hline 7 & $101-150$ & MDP & 4 & 9 & 5 & 9.0 & 19.1 & 15.7 & 24.8 \\
\hline 8 & $151-250$ & MDP & 4 & 10 & 5 & 16.5 & 24.1 & 18.4 & 31.7 \\
\hline 9 & $>250$ & MDP & 1 & 14 & 23 & 16.6 & 24.4 & 22.6 & 37.4 \\
\hline
\end{tabular}

${ }^{1} \mathrm{FDP}=$ first dry period cows; $\mathrm{MDP}=$ multiple dry period cows.

and $>150,000$ cells $/ \mathrm{mL}$ ) and 5 classes of MDP cows (0-50,000 cells/mL; 51,000-100,000 cells/mL; 101,000150,000 cells $/ \mathrm{mL} ; \quad 151,000-250,000$ cells $/ \mathrm{mL}$; and $>250,000$ cells $/ \mathrm{mL}$ ). For each of these cow groups there were 2 options regarding DCT $(j=1,2)$, either dried off with (1) or without (2) dry cow antimicrobials. Thus, in total 18 units of activity were included in the model.

Three different types of herds with respect to bulk tank SCC (BTSCC) were defined. One with a low BTSCC $<150,000$ cells $/ \mathrm{mL}\left(\mathbf{B T}_{\mathbf{L}}\right)$, one with an average $\mathrm{BTSCC} \geq 150,000$ cells $/ \mathrm{mL}$ and $<250,000$ cells $/ \mathrm{mL}$ $\left(\mathbf{B T}_{\mathbf{A}}\right)$, and one with a high BTSCC $\geq 250,000$ cells/ $\mathrm{mL}$ but $<400,000$ cells $/ \mathrm{mL}\left(\mathbf{B T}_{\mathbf{H}}\right)$, based on Barkema et al. (1998). The distribution of cows over the 9 cow groups (1-9) for a $\mathrm{BT}_{\mathrm{L}}, \mathrm{BT}_{\mathrm{A}}$, and $\mathrm{BT}_{\mathrm{H}}$ herd (Table 1) was based on the approach of Huijps et al. (2008) and on Dutch averages.

\section{Model Description}

Total economic costs of mastitis are the sum of preventive costs and failure costs. The preventive costs were the costs for use of DCT, where other preventive costs were not evaluated in this paper because they were assumed to be the same for the different approaches. Failure costs are the economic values of the losses and the economic values of the expenditures related to the occurrence of mastitis. Losses are costs associated with a cow being affected by CM or SCM (e.g., production losses, culling, discarded milk). Expenditures are the payments made by the farmer to treat mastitis.

Calculation of the total economic costs of mastitis $\left(\mathbf{T C}_{\mathbf{M}}\right)$ for the example herd was done by summing the total costs of mastitis per unit of activity $\left(\mathrm{TC}_{\mathrm{M}_{i j}}\right)$, mul- tiplied by the number of cows in each unit of activity $\left(\mathbf{N}_{i j}\right)$ :

$$
\mathrm{TC}_{\mathrm{M}}=\sum_{i=1}^{9} \sum_{j=1}^{2} \mathrm{TC}_{\mathrm{M}_{i j}} \times \mathrm{N}_{i j}
$$

where $\mathrm{TC}_{\mathrm{M}}=$ total economic costs of mastitis, $i=$ cow group 1 to $9, j=$ treatment with (1) or without (2) dry cow antimicrobials, $\mathrm{TC}_{\mathrm{M}_{i j}}=$ total costs of mastitis per unit of activity, and $\mathrm{N}_{i j}=$ the number of cows in each unit of activity.

The total economic costs of mastitis per unit of activity $\left(\mathrm{TC}_{\mathrm{M}_{i j}}\right)$ are the sum of the total costs of $\mathrm{CM}$, SCM, and DCT per unit of activity:

$$
\mathrm{TC}_{\mathrm{M}_{i j}}=\mathrm{TC}_{\mathrm{CM}_{i j}}+\mathrm{TC}_{\mathrm{SCM}_{i j}}+\mathrm{TC}_{\mathrm{DCT}_{i j}} \cdot
$$

The total costs of $\mathrm{CM}$ in each unit of activity $\left(\mathrm{TC}_{\mathrm{CM}_{i j}}\right)$ are the incidence of $\mathrm{CM}$ in this unit of activity $\left(\mathbf{I}_{\mathbf{C M}_{i j}}\right)$ multiplied with the number of cows in this unit of activity $\left(\mathrm{N}_{i j}\right)$ and the costs of a case of $\mathrm{CM}\left(\mathrm{C}_{\mathrm{CM}}\right)$ :

$$
\mathrm{TC}_{\mathrm{CM}_{i j}}=\mathrm{I}_{\mathrm{CM}_{i j}} \times \mathrm{N}_{i j} \times \mathrm{C}_{\mathrm{CM}} .
$$

The total costs of SCM in each unit of activity $\left(\mathrm{TC}_{\mathrm{SCM}_{i j}}\right)$ are derived equally by multiplying the incidence of $\mathrm{SCM}$ in this unit of activity $\left(\mathrm{I}_{\mathrm{SCM}_{i j}}\right)$ with the number of cows in this unit of activity $\left(\mathrm{N}_{i j}\right)$ and the costs of a case of $\mathrm{SCM}\left(\mathrm{C}_{\mathrm{SCM}}\right)$ : 


$$
\mathrm{TC}_{\mathrm{SCM}_{i j}}=\mathrm{I}_{\mathrm{SCM}_{i j}} \times \mathrm{N}_{i j} \times \mathrm{C}_{\mathrm{SCM}} .
$$

The total costs of DCT in each unit of activity $\left(\mathrm{TC}_{\mathrm{DCT}_{i j}}\right)$ are the number of cows to be dried off in this unit of activity $\left(\mathrm{N}_{\mathrm{DCT}_{i j}}\right)$ times the costs per cow for dry cow treatment $\left(\mathbf{C}_{\mathbf{D C T}}\right)$ :

$$
\mathrm{TC}_{\mathrm{DCT}_{i j}}=\mathrm{N}_{\mathrm{DCT}_{i j}} \times \mathrm{C}_{\mathrm{DCT}_{j}} .
$$

For cows dried off without antimicrobials $(j=2)$, there are no costs of $\mathrm{DCT}\left(\mathrm{TC}_{\mathrm{DCT}_{i j}}=0\right)$.

Data on all individual antimicrobial treatments regarding $\mathrm{CM}$ and $\mathrm{DCT}$ were collected during the field trial, consisting of active compound, application route, dosage, frequency, and duration of treatment. Antimicrobial usage for DCT and CM treatments was expressed as the calculated number of animal defined daily dosage (ADDD; i.e., the average number of days a cow receives antimicrobial treatment). One ADDD is defined as a standardized 1-d treatment, being the average dose for a 1-d treatment of a registered veterinary drug for its main indication. A cow dried off with antimicrobials was calculated as 4.0 ADDD (SantmanBerends et al., 2016), and a case of CM as 3.0 ADDD, including both intramammary and parenteral treatment (Scherpenzeel et al., 2016). Antimicrobial treatment of SCM during lactation was not taken into account.

\section{Parameterization}

The example herd had a herd size of 100 dairy cows with an average age distribution of Dutch dairy herds (CRV, 2015), in which $33 \%$ of animals had calved once and $67 \%$ had calved twice or more. Given a calving interval of $412 \mathrm{~d}$ (CRV, 2015), an average culling rate of lactating cows in Dutch dairy herds of $30 \%$ (Mohd Nor et al., 2014), and $90 \%$ of cows to be culled that were not dried off, the total number of cows for drying-off during a year in the example herd was 75 , of which 25 were FDP cows and 50 were MDP cows. The distribution of high-SCC and low-SCC animals was based on cow-level SCC data from the last milk recording before drying off of all animals of 97 herds included in a previously described field trial (Scherpenzeel et al., 2016). Cows that were dried off were grouped based on parity (FDP/MDP) and SCC at the last milk recording before drying off.

The failure costs for a case of CM were calculated based on the average costs for CM cases during the first 3 mo of lactation and were adapted from Huijps et al. (2008). In that study, all cost categories, such as milk production losses, discarded milk, veterinary support, drugs, labor, and culling were included, but were based on a quotum situation. In our study, the average costs for a $\mathrm{CM}$ case were recalculated based on the calculation method of Huijps et al. (2008) and using an average milk price levels in the post-quotum era of $€ 0.35 / \mathrm{kg}$ and an average price level of concentrate feed costs of $€ 0.13 / \mathrm{kg}$ of milk, making the net costs of milk production losses $€ 0.22 / \mathrm{kg}$ of milk. Based on that, the costs of a case of CM in the first 100 DIM were set at $€ 242$.

The failure costs for a case of SCM were calculated as milk production losses due to SCM multiplied by the related costs per kilogram of milk loss. Halasa et al. (2009b) estimated milk production losses for different levels of increased SCC without differentiating parities and calculated that the average milk production loss of all cows with cow-level SCC $>200,000$ cells $/ \mathrm{mL}$ was $0.87 \mathrm{~kg} / \mathrm{d}$. We set the average duration of an SCM case, irrespective of the causative pathogen at $85 \mathrm{~d}$, based on Lam et al. (1997). The costs of production losses due to SCM were calculated as above, and were €0.22/ $\mathrm{kg}$. Thus, the economic losses for a case of SCM were $€ 16.27$ per case.

The preventive costs of DCT consisted of AMU and labor of the farmer. It was estimated that it took on average 15 min to correctly dry-off a cow, at an hourly rate of $€ 18$, leading to $€ 4.50$ per cow (Halasa et al., $2009 \mathrm{~b})$. The costs for dry-cow antimicrobials were assumed to be $€ 11.00 /$ cow, which makes $\mathrm{C}_{\mathrm{DCT}_{1}} € 15.50$. The milk price was calculated by taking the average prices over the last $5 \mathrm{yr}$ from the Agrimatie database (Agrimatie, 2016).

Cow-level incidences of CM and SCM (Table 1) were based on quarter-level incidences from the field study for low-SCC cows, assuming that on average $1.3 \mathrm{CM}$ quarters were affected per cow. For high-SCC cows, assumptions were based on literature from Barkema et al. (1998), as is described in more detail in Scherpenzeel et al. (2016).

\section{Optimization}

The LP model in the optimization phase will select cows within the groups $(i=1-9)$ for being dried off with $(j=1)$ or without $(j=2)$ dry cow antibiotics. The optimal situation for the example herd is the situation in which $\mathrm{TC}_{\mathrm{M}}$ is lowest. To calculate this, the LP model will give the minimal $\mathrm{TC}_{\mathrm{M}}$ related to mastitis in the dry period and first 100 DIM, based on the number of cows affected by CM and SCM and the amount of antimicrobials used for each unit of activity for different herd situations based on BTSCC. 
The restrictions for the groups in the model were

$$
\sum_{i=1}^{9} \mathrm{~N}_{i 1} \leq \mathrm{P}_{\mathrm{DCT}} \times \mathrm{N}
$$

where $\mathrm{P}_{\mathrm{DCT}}=$ the maximum percentage of cows to be dried off with antimicrobials, and

$$
\mathrm{N}_{i 1}+\mathrm{N}_{i 2}=\mathrm{N}_{i j}
$$

where $\mathrm{N}_{i j}=$ the number of cows per unit of activity.

\section{Simulation}

In the optimization part of the study, the LP model was used while restricting the maximum percentage of cows dried off with antimicrobials in SDCT from 100 to $0 \%$. This restriction reveals the relationship between the percentage of cows dried off with antimicrobials and the economic consequences. The number of cows to be dried off with antimicrobials was reduced by steps of $5 \%$, leading to 21 restriction levels, and for every level the LP model was run. Based on the restriction level, the LP model selected the cows in each group for being treated $(j=1)$ or not being treated $(j=2)$ with dry cow antimicrobials at drying off, to find the situation with the lowest $\mathrm{TC}_{\mathrm{M}}$ in the dry period and the first 100 DIM. Additionally, the average incidence of CM and SCM and the ADDD were calculated by the model for every restriction level.

In the baseline level, all cows were allowed to be dried off with dry cow antimicrobials (100\%). Drying off none of the cows with antimicrobials $(0 \%)$ was the other extreme. All other levels applied SDCT, and cows were selected by the model for being treated with $(j=$ $1)$ or without $(j=2)$ dry cow antimicrobials, depending on their parity (FDP or MDP) and their SCC at the last milk recording before drying off.

\section{Variation in Herd Level CM Incidence}

Clinical mastitis is an expensive disease (Hogeveen et al., 2011) and strongly influences $\mathrm{TC}_{\mathrm{M}}$. Because $\mathrm{CM}$ incidence can vary in herds with the same BTSCC (Barkema et al., 1998), we varied the initial incidence of CM per unit of activity as input parameter within the 3 types of herds. Thus, we modeled $\mathrm{BT}_{\mathrm{L}}, \mathrm{BT}_{\mathrm{A}}$, and $\mathrm{BT}_{\mathrm{H}}$ herds with low $\left(\mathrm{BT}_{\mathrm{L}} \mathrm{C}_{\mathrm{L}}, \mathrm{BT}_{\mathrm{A}} \mathrm{C}_{\mathrm{L}}, \mathrm{BT}_{\mathrm{H}} \mathrm{C}_{\mathrm{L}}\right)$, average $\left(\mathrm{BT}_{\mathrm{L}} \mathrm{C}_{\mathrm{A}}, \mathrm{BT}_{\mathrm{A}} \mathrm{C}_{\mathrm{A}}, \mathrm{BT}_{\mathrm{H}} \mathrm{C}_{\mathrm{A}}\right)$, and high $\left(\mathrm{BT}_{\mathrm{L}} \mathrm{C}_{\mathrm{H}}, \mathrm{BT}_{\mathrm{A}} \mathrm{C}_{\mathrm{H}}\right.$, $\left.\mathrm{BT}_{\mathrm{H}} \mathrm{C}_{\mathrm{H}}\right)$ incidence of $\mathrm{CM}$ as the initial situation. These incidences per type of herd were calculated by summing the multiplications of doubled (for high incidence) or halved (for low incidence) $\mathrm{I}_{\mathrm{CM}_{i j}}$ per unit of activity multiplied with $\mathrm{N}_{i j}$, and divided by 75 animals (formulas [8] and $[9])$.

$$
\begin{aligned}
& \mathrm{C}_{\mathrm{H}}=\sum_{i=1}^{9} \mathrm{I}_{\mathrm{CM}_{i j}} \times 2.0 \times \mathrm{N}_{i j} / 75 \text { cows, } \\
& \mathrm{C}_{\mathrm{L}}=\sum_{i=1}^{9} \mathrm{I}_{\mathrm{CM}_{i j}} \times 0.5 \times \mathrm{N}_{i j} / 75 \text { cows, }
\end{aligned}
$$

where $\mathrm{I}_{\mathrm{CM}_{i j}}=$ the incidence of $\mathrm{CM}$ in this unit of activity.

Variation in the initial situation of the incidence of CM per unit of activity led to variance in the dependent output variable, being the mean herd-level incidence of CM.

\section{Sensitivity Analysis}

A sensitivity analysis was performed to evaluate the effect of variation in the most important input variables, being the effect of dry cow antimicrobials $\left(\boldsymbol{\Delta}_{\mathrm{DCT}}\right)$ resulting in a lower or higher incidence of CM and SCM and the effect of milk price. Both these parameters directly affect the most important output variable in this study, $\mathrm{TC}_{\mathrm{M}}$. To evaluate the effect of the use of dry cow antimicrobials, $\Delta_{\mathrm{DCT}}$ was varied per group by multiplying the difference between $\mathrm{I}_{\mathrm{CM}_{i 1}}$ and $\mathrm{I}_{\mathrm{CM}_{i 2}}$ per group with 0.5 as the lower limit and with 2.0 as the upper limit. The incidences of $\mathrm{CM}$ and SCM in the treated groups were the constant baseline and the incidences of $\mathrm{CM}$ and SCM in the untreated groups were varied, to analyze the sensitivity of the model. We expected that assumptions about milk price would have a substantial effect on $\mathrm{TC}_{\mathrm{M}}$. Therefore we multiplied the average milk price of $€ 35 / 100 \mathrm{~kg}$ by 0.775 as the lower limit and by 1.225 as the upper limit. This resulted in $€ 27 / 100 \mathrm{~kg}$ of milk for a low milk price and $€ 43 / 100 \mathrm{~kg}$ of milk for a high milk price. The sensitivity analysis was carried out for all 21 restriction levels in the $\mathrm{BT}_{\mathrm{L}}, \mathrm{BT}_{\mathrm{A}}$, and $\mathrm{BT}_{\mathrm{H}}$ herds to determine the effect on the minimal $\mathrm{TC}_{\mathrm{M}}$.

\section{RESULTS}

\section{Simulation}

All 21 DCT restriction levels were evaluated to study the effect of reducing the maximum percentage of cows to be dried off with antimicrobials on mastitis, AMU, and $\mathrm{TC}_{\mathrm{M}}$ during the dry period and the first 100 DIM. Results for CM, SCM, ADDD, and economics for the 
Table 2. Mean incidence of clinical mastitis $\left(\mathrm{I}_{\mathrm{CM}}\right)$, mean incidence of subclinical mastitis $\left(\mathrm{I}_{\mathrm{SCM}}\right)$, animal defined daily dosage of antimicrobials per year (ADDD), and total economic costs of mastitis per cow per year $(€)^{1}$

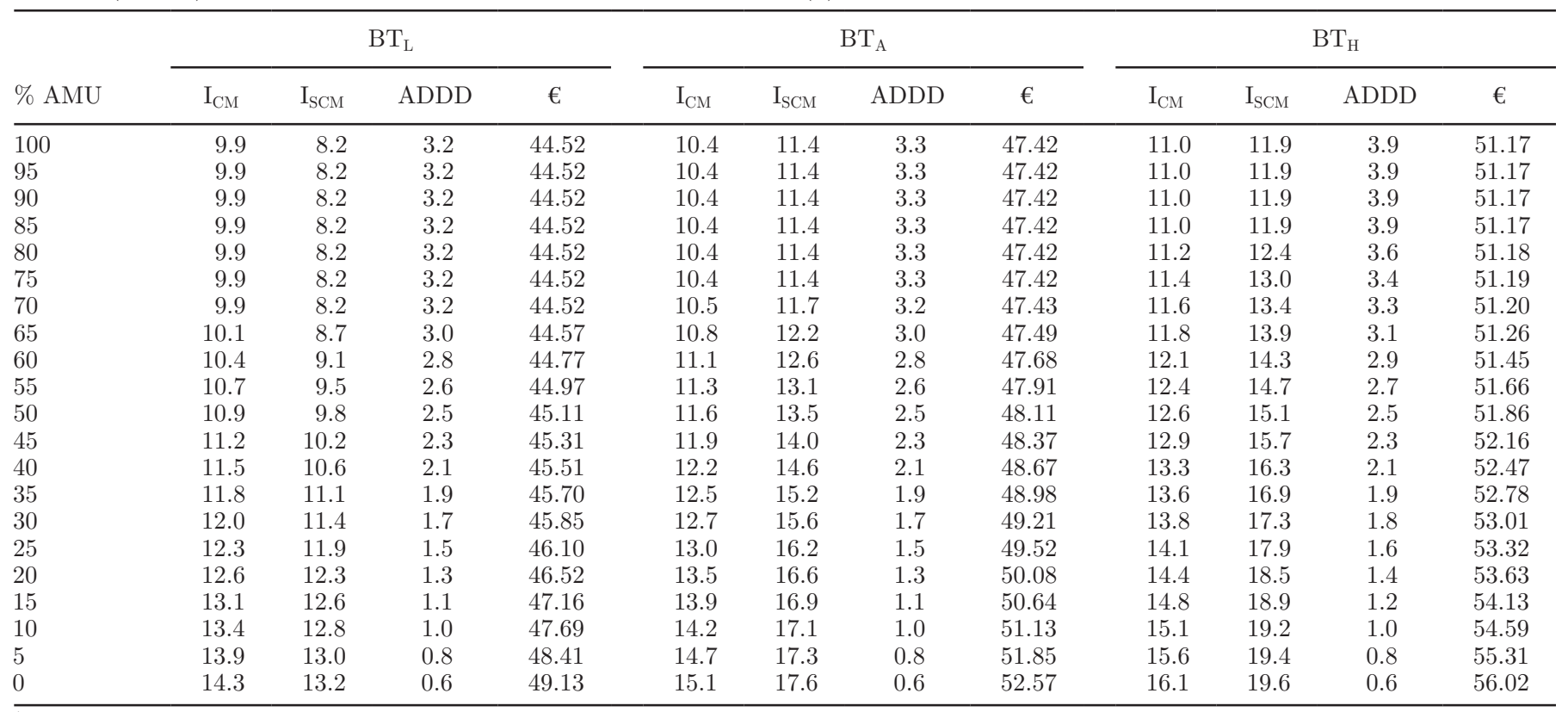

${ }^{1}$ Calculations were done using the maximum percentage of dry cow antimicrobials (\% AMU) as restriction level, which was reduced in steps of $5 \%$ from 100 to $0 \%$, for a low-bulk tank SCC (BTSCC) herd $\left(\mathrm{BT}_{\mathrm{L}}\right)$, an average-BTSCC herd $\left(\mathrm{BT}_{\mathrm{A}}\right)$, and a high-BTSCC herd $\left(\mathrm{BT}_{\mathrm{H}}\right)$.

21 restriction levels for the 3 types of herds $\left(\mathrm{BT}_{\mathrm{L}}, \mathrm{BT}_{\mathrm{A}}\right.$, $\left.\mathrm{BT}_{\mathrm{H}}\right)$ are presented in Table 2. Costs per cow to be dried off per year varied from $€ 45$ on a $\mathrm{BT}_{\mathrm{L}}$ herd where $100 \%$ of the cows were allowed to be dried off with antimicrobials to $€ 56$ on a $\mathrm{BT}_{\mathrm{H}}$ herd where no dry cow antimicrobials were allowed (Table 2). Clinical and subclinicial mastitis incidence in the different types of herds varied from 9.9 to $16.1 \%$ and from 8.2 to $19.6 \%$, respectively. Antimicrobial use varied from 0.6 ADDD when no dry cow antimicrobials were allowed $(0 \%)$ in $\mathrm{BT}_{\mathrm{L}}, \mathrm{BT}_{\mathrm{A}}$, and $\mathrm{BT}_{\mathrm{H}}$ herds to $3.9 \mathrm{ADDD}$ when $100 \%$ of cows were allowed to be dried off with antimicrobials in a $\mathrm{BT}_{\mathrm{H}}$ herd.

\section{Variation in Herd-Level CM Incidence}

Results of variation in the initial herd level CM incidence on the effect of a SDCT approach on $\mathrm{TC}_{\mathrm{M}}$ and the comparison with a BDCT approach for different types of herds are presented in Table 3 and Figure 1. If a BDCT approach was applied, $100 \%$ of the cows had to be dried off with dry cow antimicrobials and therefore the units of activity were forced in DCT group $j=1$. If a SDCT approach was applied, a maximum of $100 \%$ of dry cow antimicrobials was allowed, which does not mean that $100 \%$ of the cows were placed in the $\operatorname{DCT} \operatorname{group}(j=1)$.

Table 3. Total economic costs $(€)$ of mastitis in a blanket dry cow treatment (BDCT) approach and minimized total economic costs of mastitis when 100 and $0 \%$ dry cow antimicrobials are allowed for a 100-cow dairy herd with 75 cows to be dried off ${ }^{1}$

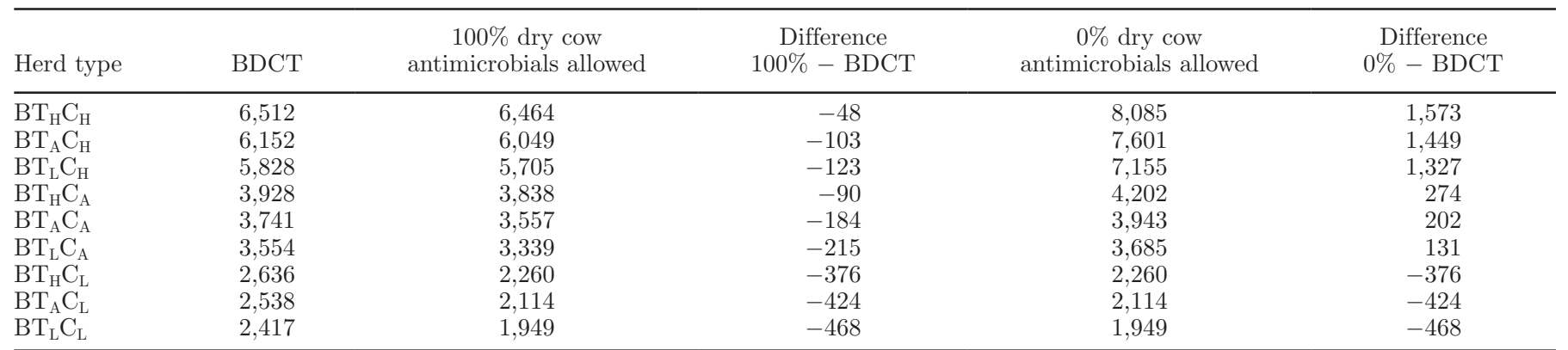

${ }^{1}$ Calculations were done for a high-bulk tank SCC (BTSCC) herd $\left(\mathrm{BT}_{\mathrm{H}}\right)$, an average-BTSCC herd $\left(\mathrm{BT}_{\mathrm{A}}\right)$, and a low-BTSCC herd $\left(\mathrm{BT}_{\mathrm{L}}\right)$, each with a low $\left(\mathrm{C}_{\mathrm{L}}\right)$, an average $\left(\mathrm{C}_{\mathrm{A}}\right)$, and a high $\left(\mathrm{C}_{\mathrm{H}}\right)$ incidence of clinical mastitis and the difference between $100 \%$ and $\mathrm{BDCT}$ and between $0 \%$ and BDCT. 
Table 3 shows that the effect of $\mathrm{CM}$ is greater than the effect of BTSCC, with BDCT being always more expensive than SDCT and no dry cow antimicrobials $(0 \%)$ being cheaper than BDCT if the incidence of $\mathrm{CM}$ is low.

When the maximum percentage of cows to be dried off with antimicrobials decreased from 100 to $0 \%, \mathrm{TC}_{\mathrm{M}}$ of an SDCT approach remained lower than the $\mathrm{TC}_{\mathrm{M}}$ for a BDCT approach, until a certain point where the $\mathrm{TC}_{\mathrm{M}}$ of SDCT becomes higher than the $\mathrm{TC}_{\mathrm{M}}$ of $\mathrm{BDCT}$ (Figure 1). For the $\mathrm{BT}_{\mathrm{H}} \mathrm{C}_{\mathrm{H}}$ herd, this point was $80 \%$, for the $\mathrm{BT}_{\mathrm{A}} \mathrm{C}_{\mathrm{H}}$ herd $65 \%$, and for the $\mathrm{BT}_{\mathrm{L}} \mathrm{C}_{\mathrm{H}}$ herd $60 \%$. For the $\mathrm{BT}_{\mathrm{H}} \mathrm{C}_{\mathrm{A}}$ herd, this point was $40 \%$, for the $\mathrm{BT}_{\mathrm{A}} \mathrm{C}_{\mathrm{A}}$ herd $20 \%$, and for the $\mathrm{BT}_{\mathrm{L}} \mathrm{C}_{\mathrm{A}}$ herd $10 \%$. When the incidence of $\mathrm{CM}$ was low $\left(\mathrm{BT}_{\mathrm{L}} \mathrm{C}_{\mathrm{L}}, \mathrm{BT}_{\mathrm{A}} \mathrm{C}_{\mathrm{L}}, \mathrm{BT}_{\mathrm{H}} \mathrm{C}_{\mathrm{L}}\right)$, in all 21 situations a SDCT approach was more beneficial than a BDCT approach.

\section{Sensitivity Analysis}

Minimal $\mathrm{TC}_{\mathrm{M}}$ was influenced by changes in $\Delta_{\mathrm{DCT}}$ and changes in milk price, as presented in Table 4 . If the effect of DCT is smaller $\left(\Delta_{\mathrm{DCT}} \times 0.5\right)$, incidence of $\mathrm{CM}$ in dry cow treated cows will be lower than in the baseline situation, as will be the $\mathrm{TC}_{\mathrm{M}}$. The effect of a decreased $\Delta_{\mathrm{DCT}}$ is substantial (up to $9 \%$ ), whereas it is limited for an increased $\Delta_{\mathrm{DCT}}$ (maximal 3\%). The sensitivity analysis showed that the variability in milk price has a substantial effect on the minimal $\mathrm{TC}_{\mathrm{M}}$ for SDCT in both directions. If the milk price was $€ 27 / 100$ $\mathrm{kg}, \mathrm{BDCT}$ was not beneficial for any type of herd (data not presented). Changing milk prices had a greater effect on minimal $\mathrm{TC}_{\mathrm{M}}$ than changing $\Delta_{\mathrm{DCT}}$, up to $16 \%$ in both directions. The lowest minimal $\mathrm{TC}_{\mathrm{M}}$ was $€ 2,809$ per year for a $\mathrm{BT}_{\mathrm{L}} \mathrm{C}_{\mathrm{A}}$ herd when the milk price was

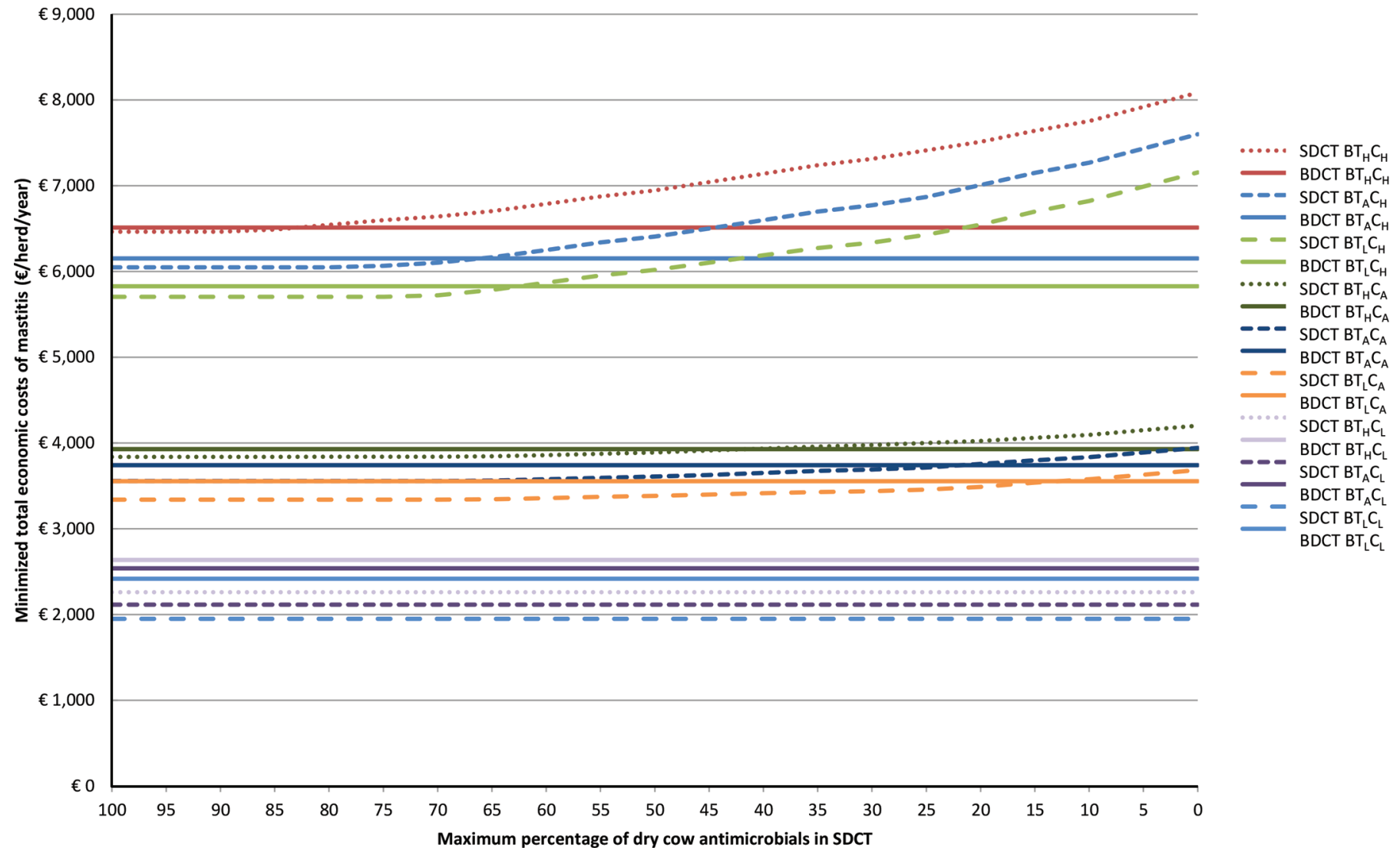

Figure 1. Minimized total economic costs of mastitis for a 100-cow dairy herd with 75 cows to be dried off applying selective dry cow treatment (dashed lines) and reducing the maximum percentage of dry cow antimicrobials from 100 to $0 \%$ for a low-bulk tank SCC (BTSCC) herd $\left(\mathrm{BT}_{\mathrm{L}}\right)$, an average-BTSCC herd $\left(\mathrm{BT}_{\mathrm{A}}\right)$, and a high-BTSCC herd $\left(\mathrm{BT}_{\mathrm{H}}\right)$, each with a low $\left(\mathrm{BT}_{\mathrm{L}} \mathrm{C}_{\mathrm{L}}, \mathrm{BT}_{\mathrm{A}} \mathrm{C}_{\mathrm{L}}, \mathrm{BT}_{\mathrm{H}} \mathrm{C}_{\mathrm{L}}\right)$, an average $\left(\mathrm{BT}_{\mathrm{L}} \mathrm{C}_{\mathrm{A}}, \mathrm{BT}_{\mathrm{A}} \mathrm{C}_{\mathrm{A}}\right.$, $\mathrm{BT}_{\mathrm{H}} \mathrm{C}_{\mathrm{A}}$ ), and a high $\left(\mathrm{BT}_{\mathrm{L}} \mathrm{C}_{\mathrm{H}}, \mathrm{BT}_{\mathrm{A}} \mathrm{C}_{\mathrm{H}}, \mathrm{BT}_{\mathrm{H}} \mathrm{C}_{\mathrm{H}}\right.$ ) incidence of clinical mastitis (selective dry cow treatment; SDCT) and for blanket dry cow treatment (BDCT; solid lines) in these 9 types of herds. Color version available online. 
$€ 27 / 100 \mathrm{~kg}$. The highest minimal $\mathrm{TC}_{\mathrm{M}}$ was $€ 4,422$ per year for a $\mathrm{BT}_{\mathrm{H}} \mathrm{C}_{\mathrm{A}}$ herd when the milk price was $€ 43 / 100 \mathrm{~kg}$.

\section{DISCUSSION}

To control mastitis, much research has been done to evaluate the effects of DCT, generally indicating a positive effect of DCT on udder health (Halasa et al., 2009a). Due to a changing view on AMU in the animal industry, preventive use of antimicrobials, including BDCT, is no longer allowed in several European countries, including the Netherlands (Santman-Berends et al., 2016). Economic consequences likely contribute to farmers' decision-making on the use of dry cow antimicrobials and therefore are of interest with regard to SDCT as compared with BDCT.

Our model compared different SDCT approaches based on monthly SCC. Some studies have used quarter-, cow-, and herd-level criteria to select cows for dry cow therapy. Decision-making to select cows for DCT can be based on bacteriological culture (Browning et al., 1990; Cameron et al., 2014), SCC and CM history (Rindsig et al., 1978; Torres et al., 2008; Rajala-Schultz et al., 2011), the California mastitis test (Rindsig et al., 1978; Bhutto et al., 2012), and $N$-acetyl- $\beta$-Dglucosaminidase (Hassan et al., 1999) with different accuracies in identification of infected cows. The most feasible selection method, however, is based on monthly SCC, which has a reported sensitivity of $70 \%$ and specificity of $63 \%$ to identify quarters with IMI at drying off (Torres et al., 2008). These are not ideal test characteristics, which may lead to false positive or false negatives in cow selection for DCT. This, however, was found not to lead to big problems when implemented in field studies (Scherpenzeel et al., 2016).
Although epidemiological consequences and effects of reducing DCT were extensively evaluated in the last 3 yr (Cameron et al., 2014; Santman-Berends et al., 2016; Scherpenzeel et al., 2016), attention to economic consequences of different approaches of DCT was limited to a few studies in the last 10 yr (Halasa et al., 2007; Huijps and Hogeveen, 2007). In our study, our main finding was that from an economic perspective, although differences were small, BDCT seems not to be the optimal approach of DCT. The maximum percentage of cows to be dried off with dry cow antimicrobials in an SDCT approach could, in herds with different BTSCC and CM incidence levels, be decreased to a certain level without seeing an increase in $\mathrm{TC}_{\mathrm{M}}$.

We found that the maximum percentage of dry cow antimicrobials in SDCT, where the minimal $\mathrm{TC}_{\mathrm{M}}$ for SDCT equals $\mathrm{TC}_{\mathrm{M}}$ for BDCT, is influenced by the udder health situation of a herd, both by BTSCC as well as CM. The effect of the incidence of CM, as well as the BTSCC, were evaluated, showing that the effect of the incidence of $\mathrm{CM}$ on minimal $\mathrm{TC}_{\mathrm{M}}$ was much greater than the effect of BTSCC. This indicated that BDCT is not the economically optimal DCT approach as compared with $100 \%$ SDCT in all types of herds and as compared with $0 \%$ SDCT in all types of BTSCC herds with a low incidence of $\mathrm{CM}\left(\mathrm{BT}_{\mathrm{L}} \mathrm{C}_{\mathrm{L}}, \mathrm{BT}_{\mathrm{A}} \mathrm{C}_{\mathrm{L}}, \mathrm{BT}_{\mathrm{H}} \mathrm{C}_{\mathrm{L}}\right)$.

Comparison of the $\mathrm{TC}_{\mathrm{M}}$ for a $\mathrm{BDCT}$ approach and the minimal $\mathrm{TC}_{\mathrm{M}}$ for SDCT showed limited economic effects due to small differences between different approaches. This is in line with the findings of Huijps and Hogeveen (2007), who concluded that SDCT was economically the best approach to dry off cows, although the differences with BDCT were small. They concluded that a small change in the probabilities of the rate of infection and costs associated with mastitis moved the economically optimal decision toward BDCT. Assump-

Table 4. Results of the sensitivity analysis by halving and doubling the effect of dry cow treatment $\left(\Delta_{\text {DCT }}\right)$ and variation in milk price on the calculated minimal total economic costs of mastitis $\left(\mathrm{TC}_{\mathrm{M}}\right)^{1}$

\begin{tabular}{|c|c|c|c|c|c|c|}
\hline \multirow[b]{3}{*}{ Sensitivity analysis } & \multicolumn{6}{|c|}{ Minimal $\mathrm{TC}_{\mathrm{M}}$} \\
\hline & \multicolumn{2}{|c|}{$\mathrm{BT}_{\mathrm{L}} \mathrm{C}_{\mathrm{A}}$} & \multicolumn{2}{|c|}{$\mathrm{BT}_{\mathrm{A}} \mathrm{C}_{\mathrm{A}}$} & \multicolumn{2}{|c|}{$\mathrm{BT}_{\mathrm{H}} \mathrm{C}_{\mathrm{A}}$} \\
\hline & $€ /$ yr per herd & $\%$ & $€ /$ yr per herd & $\%$ & $€ /$ yr per herd & $\%$ \\
\hline Baseline, $100 \% \mathrm{SDCT}^{2}$ & 3,339 & & 3,557 & & 3,838 & \\
\hline$\Delta_{\mathrm{DCT}} \times 0.5$ & 3,038 & -9 & 3,261 & -8 & 3,484 & -9 \\
\hline$\Delta_{\mathrm{DCT}} \times 2.0$ & 3,445 & +3 & 3,665 & +3 & 3,887 & +1 \\
\hline Milk price, $€ 27 / 100 \mathrm{~kg}$ & 2,809 & -16 & 2,982 & -16 & 3,205 & -16 \\
\hline Milk price, $€ 43 / 100 \mathrm{~kg}$ & 3,850 & +15 & 4,113 & +16 & 4,422 & +15 \\
\hline
\end{tabular}

${ }^{1}$ Calculations were done for a low-bulk tank SCC (BTSCC) herd $\left(\mathrm{BT}_{\mathrm{L}} \mathrm{C}_{\mathrm{A}}\right)$, an average-BTSCC herd $\left(\mathrm{BT}_{\mathrm{A}} \mathrm{C}_{\mathrm{A}}\right)$, and a high-BTSCC herd $\left(\mathrm{BT}_{\mathrm{H}} \mathrm{C}_{\mathrm{A}}\right)$ with an average incidence of clinical mastitis when $100 \%$ of cows are allowed to be dried off with antimicrobials.

${ }^{2} \mathrm{SDCT}=$ selective dry cow treatment. 
tions on failure and preventive costs to estimate $\mathrm{TC}_{\mathrm{M}}$, however, can differ per herd. We used the best available estimates for the Dutch situation to prevent potential bias as much as possible. The sensitivity analysis showed that the effect of variability in milk price and changes in $\Delta_{\mathrm{DCT}}$ has substantial effect on the $\mathrm{TC}_{\mathrm{M}}$, although the conclusions do not change. This shows that the conclusions using our deterministic approach are robust.

Evaluating the effect of the incidence of $\mathrm{CM}$ in a $\mathrm{BT}_{\mathrm{A}}$ herd showed a great effect on the minimized $\mathrm{TC}_{\mathrm{M}}$ (Figure 1). The minimized $\mathrm{TC}_{\mathrm{M}}$ was 3 times higher for a $\mathrm{BT}_{\mathrm{A}} \mathrm{C}_{\mathrm{H}}$ herd than for a $\mathrm{BT}_{\mathrm{A}} \mathrm{C}_{\mathrm{L}}$ herd. In a $\mathrm{BT}_{\mathrm{H}}$ herd, effects of the incidence of $\mathrm{CM}$ were similar to a $\mathrm{BT}_{\mathrm{L}}$ herd (Figure 1) as they were in a $\mathrm{BT}_{\mathrm{A}}$ herd (results not shown). In all types of herds, the minimal $\mathrm{TC}_{\mathrm{M}}$ for a low incidence of CM was always lower for SDCT than for BDCT (Figure 1). The largest difference in minimal $\mathrm{TC}_{\mathrm{M}}$ when applying $100 \%$ SDCT was between a $\mathrm{BT}_{\mathrm{H}}$ herd with a high incidence of $\mathrm{CM}\left(\mathrm{BT}_{\mathrm{H}} \mathrm{C}_{\mathrm{H}}\right)$ and a $\mathrm{BT}_{\mathrm{L}}$ herd with a low incidence of $\mathrm{CM}\left(\mathrm{BT}_{\mathrm{L}} \mathrm{C}_{\mathrm{L}}\right)$, being $€ 4,515$ per year per herd.

In our optimization model, the relation between DCT and the incidence of CM and SCM was modeled in a straightforward manner. The limitation of the optimization approach is that some parameters and associations need to be assumed. We were, however, able to base the probabilities of mastitis on a large prospective field trial. In this field trial, no internal teat sealants were used, although the use of internal teat sealant is an important preventive tool. Usage of internal teat sealants was previously found to have a protective effect on the incidence of new CM cases because teat sealants help prevent colonization of quarters with bacteria during the dry period (Rabiee and Lean, 2013). A model including the effect of the use of internal teat sealants would be worthwhile, but was beyond the scope of this study.

The economic effect of an improved udder health situation on the herd (e.g., having a lower BTSCC or a lower incidence of $\mathrm{CM}$ ) is much greater than the economic effect of restricting the maximum percentage of dry cow antimicrobials used. For the minimal $\mathrm{TC}_{\mathrm{M}}$ on some types of herds (e.g., a $\mathrm{BT}_{\mathrm{H}} \mathrm{C}_{\mathrm{A}}$ herd), economic benefits of SDCT were very small, as compared with a BDCT approach. From a risk avoidance approach, one could therefore choose for a BDCT approach. For reasons of prudent $\mathrm{AMU}$, however, it is not desirable to use more dry cow antimicrobials than needed and there also seems to be no economic reason to do so. Thus, for several reasons investments and efforts should be made to reduce BTSCC and the incidence of $\mathrm{CM}$, rather than using more dry cow antimicrobials.
For all BTSCC levels, it was economically beneficial to reduce the incidence of $\mathrm{CM}$ to improve general udder health management. While searching for the economically optimal DCT approach, we compared udder health and AMU, because of opposite effects of limiting the use of dry cow antimicrobials on these parameters. When searching for optimal selection criteria for DCT, the incidence of mastitis, BTSCC, and AMU can be compared in an economic evaluation. This oversimplifies the potential effect of DCT, given the potential effect of AMR, the public opinion on preventive AMU, political issues, and animal welfare. This study, however, shows that economics is not an argument against reduction of the use of dry cow antimicrobials by applying SDCT.

\section{CONCLUSIONS}

From an economic perspective, BDCT seems not to be the optimal approach of DCT, although differences between approaches were small. For all evaluated BTSCC levels, SDCT was economically more beneficial than BDCT with greater economic profits in herds with lower incidence of CM and lower BTSCC. In all types of herds, the use of dry cow antimicrobials can be reduced without economic consequences. In herds with low incidence of CM the use of no dry cow antimicrobials at all is cheaper than BDCT. The economic impact of improvement of the udder health situation, both the incidence of CM and BTSCC, however, is bigger than the effect of the DCT approach. Economics is not an argument against reduction of the use of dry cow antimicrobials by applying SDCT.

\section{ACKNOWLEDGMENTS}

This study was financially supported by the Dutch Dairy Board (PZ, Zoetermeer, the Netherlands). The authors appreciate the cooperation of the dairy producers who contributed to the field study the data used in this paper were based on.

\section{REFERENCES}

Agrimatie. 2016. Annual prices of the most important products and production equipment for the dairy sector as based on information from the Farm Accountancy Data Network. Vol. 2016. Accessed Apr. 25, 2016. www.agrimatie.nl.

Barkema, H. W., Y. H. Schukken, T. J. G. M. Lam, M. L. Beiboer, H. Wilmink, G. Benedictus, and A. Brand. 1998. Incidence of clinical mastitis in dairy herds grouped in three categories by bulk milk somatic cell counts. J. Dairy Sci. 81:411-419.

Berry, E. A., and J. E. Hillerton. 2002. The effect of selective dry cow treatment on new intramammary infections. J. Dairy Sci. $85: 112-121$. 
Berry, S. L., J. Maas, J. H. Kirk, J. P. Reynolds, I. A. Gardner, and A. Ahmadi. 1997. Effects of antimicrobial treatment at the end of lactation on milk yield, somatic cell count, and incidence of clinical mastitis during the subsequent lactation in a dairy herd with a low prevalence of contagious mastitis. J. Am. Vet. Med. Assoc. 211:207-211.

Bhutto, A. L., R. D. Murray, and Z. Woldehiwet. 2012. California mastitis test scores as indicators of subclinical intra-mammary infections at the end of lactation in dairy cows. Res. Vet. Sci. 92:13-17.

Bradley, A. J., and M. J. Green. 2001. An investigation of the impact of intramammary antibiotic dry cow therapy on clinical coliform mastitis. J. Dairy Sci. 84:1632-1639.

Browning, J. W., G. A. Mein, M. Barton, T. J. Nicholls, and P. Brightling. 1990. Effects of antibiotic therapy at drying off on mastitis in the dry period and early lactation. Aust. Vet. J. 67:440-442.

Cameron, M., S. L. McKenna, K. A. MacDonald, I. R. Dohoo, J. P. Roy, and G. P. Keefe. 2014. Evaluation of selective dry cow treatment following on-farm culture: Risk of postcalving intramammary infection and clinical mastitis in the subsequent lactation. J. Dairy Sci. 97:270-284.

Chantziaras, I., F. Boyen, B. Callens, and J. Dewulf. 2014. Correlation between veterinary antimicrobial use and antimicrobial resistance in food-producing animals: A report on seven countries. J. Antimicrob. Chemother. 69:827-834.

CRV. 2015. Jaarstatistieken 2015: Dutch Royal Cattle Syndicate Annual Report (in Dutch). Accessed Apr. 25, 2016. https://www .crv4all.nl/downloads/prestaties/jaarstatistieken.

Dodd, F. H., D. R. Westgarth, F. K. Neave, and R. G. Kingwill. 1969. Mastitis-The strategy of control. J. Dairy Sci. 52:689-695.

Halasa, T., K. Huijps, O. Osteras, and H. Hogeveen. 2007. Economic effects of bovine mastitis and mastitis management: a review. Vet. Q. 29:18-31

Halasa, T., M. Nielen, A. P. W. De Roos, R. Van Hoorne, G. de Jong, T. J. G. M. Lam, T. van Werven, and H. Hogeveen. 2009b. Production loss due to new subclinical mastitis in Dutch dairy cows estimated with a test-day model. J. Dairy Sci. 92:599-606.

Halasa, T., O. Osteras, H. Hogeveen, T. van Werven, and M. Nielen. 2009a. Meta-analysis of dry cow management for dairy cattle. Part 1. Protection against new intramammary infections. J. Dairy Sci. 92:3134-3149.

Hassan, Z., R. C. Daniel, D. O'Boyle, and A. J. Frost. 1999. Effects of dry cow intramammary therapy on quarter infections in the dry period. Vet. Rec. 145:635-639.

Hogeveen, H., K. Huijps, and T. J. G. M. Lam. 2011. Economic aspects of mastitis: New developments. N. Z. Vet. J. 59:16-23.

Huijps, K., and H. Hogeveen. 2007. Stochastic modeling to determine the economic effects of blanket, selective, and no dry cow therapy. J. Dairy Sci. 90:1225-1234

Huijps, K., T. J. G. M. Lam, and H. Hogeveen. 2008. Costs of mastitis: Facts and perception. J. Dairy Res. 75:113-120.

Kuipers, A., W. J. Koops, and H. Wemmenhove. 2016. Antibiotic use in dairy herds in the Netherlands from 2005 to 2012. J. Dairy Sci. 99:1632-1648.
Lam, T. J. G. M., Y. H. Schukken, J. H. van Vliet, F. J. Grommers, M. J. Tielen, and A. Brand. 1997. Effect of natural infection with minor pathogens on susceptibility to natural infection with major pathogens in the bovine mammary gland. Am. J. Vet. Res. $58: 17-22$

Lam, T. J. G. M., B. H. P. van den Borne, J. Jansen, K. Huijps, J. C. van Veersen, G. van Schaik, and H. Hogeveen. 2013. Improving bovine udder health: A national mastitis control program in the Netherlands. J. Dairy Sci. 96:1301-1311.

McNab, W. B., and A. H. Meek. 1991. A benefit cost analysis of dry-cow mastitis therapy in Ontario dairy herds. Can. Vet. J. 32:347-353.

Mohd Nor, N., W. Steeneveld, and H. Hogeveen. 2014. The average culling rate of Dutch dairy herds over the years 2007 to 2010 and its association with herd reproduction, performance and health. J. Dairy Res. 81:1-8.

Neave, F. K., F. H. Dodd, R. G. Kingwill, and D. R. Westgarth. 1969. Control of mastitis in the dairy herd by hygiene and management. J. Dairy Sci. 52:696-707.

Oliver, S. P. S. E. Murinda, and B. M. Jayarao. 2011. Impact of antibiotic use in adult dairy cows on antimicrobial resistance of veterinary and human pathogens: A comprehensive review. Foodborne Pathog. Dis. 8:337-355.

Rabiee, A. R., and I. J. Lean. 2013. The effect of internal teat sealant products (Teatseal and Orbeseal) on intramammary infection, clinical mastitis, and somatic cell counts in lactating dairy cows: A meta-analysis. J. Dairy Sci. 96:6915-6931.

Rajala-Schultz, P. J., A. H. Torres, and F. J. Degraves. 2011. Milk yield and somatic cell count during the following lactation after selective treatment of cows at dry-off. J. Dairy Res. 78:489-499.

Rindsig, R. B., R. G. Rodewald, A. R. Smith, and S. L. Spahr. 1978. Complete versus selective dry cow therapy for mastitis control. J. Dairy Sci. 61:1483-1497.

Santman-Berends, I. M. G. A., J. M. Swinkels, T. J. G. M. Lam, J. Keurentjes, and G. van Schaik. 2016. Evaluation of udder health parameters and risk factors for clinical mastitis in Dutch dairy herds in the context of a restricted antimicrobial usage policy. J. Dairy Sci. 99:2930-2939.

Scherpenzeel, C. G. M., I. E. M. den Uijl, G. van Schaik, R. G. M. Olde Riekerink, J. M. Keurentjes, and T. J. G. M. Lam. 2014 Evaluation of the use of dry cow antibiotics in low somatic cell count cows. J. Dairy Sci. 97:3606-3614.

Scherpenzeel, C. G. M., I. E. M. den Uijl, G. van Schaik, R. G. M. Riekerink, H. Hogeveen, and T. J. G. M. Lam. 2016. Effect of different scenarios for selective dry-cow therapy on udder health, antimicrobial usage, and economics. J. Dairy Sci. 99:3753-3764.

Torres, A. H., P. J. Rajala-Schultz, F. J. Degraves, and K. H. Hoblet. 2008. Using dairy herd improvement records and clinical mastitis history to identify subclinical mastitis infections at dry-off. J. Dairy Res. 75:240-247.

Yalcin, C., and A. W. Stott. 2000. Dynamic programming to investigate financial impacts of mastitis control decisions in milk production systems. J. Dairy Res. 67:515-528. 